ORIGINAL ARTICLE / ARTIGO ORIGINAL

\title{
Polypharmacy, socioeconomic indicators and number of diseases: results from ELSA-Brasil
}

\author{
Polifarmácia, indicadores socioeconômicos \\ e numero de doenças: resultados do ELSA-Brasil
}

\author{
Isabella Ribeiro Silva' (D), Luana Giatti"l (D), Dora Chor"l' (D), Maria de Jesus \\ Mendes da Fonsecall' (D), Sotero Serrate Mengue ${ }^{\mathrm{IV}}$ (D), Francisco de Assis Acurcio" (D), \\ Mariana Linhares Pereira' (D), Sandhi Maria Barreto" (D), Roberta Carvalho de Figueiredo'
}

\begin{abstract}
Objective: To estimate the prevalence of polypharmacy, describe the pharmacotherapeutic classes used, and investigate whether polypharmacy is associated with demographic and socioeconomic indicators, regardless of the number of diseases, among participants in the Brazilian Longitudinal Study of Adult Health (ELSA-Brasil) baseline (2008-2010). Method: In this analysis, 14,523 adults and elderly (35-74 years) participated. Polypharmacy was characterized as regular use of five or more medicines. The demographic and socioeconomic indicators analyzed were: gender, age, education level, per capita family income, and access to private health insurance. The independent association between demographic and economic indicators and polypharmacy was estimated by binary logistic regression. Results: The prevalence of polypharmacy was $11.7 \%$. The most used drugs were those with action on the cardiovascular system. After adjustments, including by number of diseases, the chances of being on polypharmacy treatment were significantly higher among women, older participants and those with greatest number of diseases. Individuals without health insurance had lower chance to be under polypharmacy, as well as those with lower income. Conclusion: The occurrence of polypharmacy among ELSA-Brasil baseline participants was mainly due to drugs for the treatment of chronic diseases. The relation between polypharmacy and the female gender, as well as its association with old age, are in consonance with the results obtained in other studies. Despite the absence of an association between polypharmacy and education level, the income and health insurance results reinforce the existence of social inequalities regarding drug use.
\end{abstract}

Keywords: Pharmacoepidemiology. Polypharmacy. Population Health. Drug utilization.

Universidade Federal de São João del-Rei - Divinópolis (MG), Brazil. "Universidade Federal de Minas Gerais - Belo Horizonte (MG), Brazil.

"'Fundação Oswaldo Cruz - Rio de Janeiro (RJ), Brazil.

IVUniversidade Federal do Rio Grande do Sul - Porto Alegre (RS), Brazil.

Corresponding author: Roberta Carvalho de Figueiredo. Universidade Federal de São João del-Rei, Campus Centro Oeste Dona Lindu. Rua Sebastião Gonçalves Coelho, 400, Bloco D, sala 308.3, Chanadour, CEP: 35501-296, Divinópolis, MG, Brazil. E-mail: robertafigueiredo@ufsj.edu.br

Conflict of interests: nothing to declare - Financial support: Brazilian Ministry of Health (Department of Science and Technology) and Brazilian Ministry of Science, Technology and Innovation (Financiadora de Estudos e Projetos - FINEP); Brazilian National Council for Scientific and Technological Development (Conselho Nacional de Desenvolvimento Científico e Tecnológico - CNPq), through grant nos. 01060010.00 RS, 01060212.00 BA, 01060300.00 ES, 0106 0278.00 MG, 01060115.00 SP and 01060071.00 RJ; Coordination of Superior Level Staff Improvement (Coordenação de Aperfeiçoamento de Pessoal de Nível Superior - Brasil - CAPES) - Finance Code 001. 
RESUMO: Objetivo: Estimar a prevalência de polifarmácia, descrever as classes farmacoterapêuticas utilizadas e investigar se a polifarmácia está associada a indicadores demográficos e socioeconômicos, independentemente do número de morbidades, entre os participantes na linha de base do Estudo Longitudinal de Saúde do Adulto (ELSABrasil) (2008-2010). Métodos: Participaram desta análise 14.523 adultos e idosos (35-74 anos). A polifarmácia foi caracterizada como uso regular de cinco ou mais medicamentos. Os indicadores demográficos e socioeconômicos analisados foram: sexo, idade, escolaridade, renda familiar per capita e acesso a plano de saúde particular. A associação independente entre os indicadores demográficos e econômicos e polifarmácia foi estimada por meio de regressão logística binária. Resultados: A prevalência de polifarmácia foi de 11,7\%. Os medicamentos mais utilizados foram aqueles com ação no sistema cardiovascular. Após ajustes, incluindo número de doenças, a chance de estar sob tratamento com polifarmácia foi significativamente maior entre mulheres, participantes mais velhos e aqueles com maior número de doenças. Participantes de baixa renda e aqueles sem plano privado de saúde, no entanto, tiveram menor chance de estar sob polifarmácia. Conclusão: A ocorrência de polifarmácia entre os participantes da linha de base do ELSA-Brasil deveu-se principalmente a medicamentos para o tratamento de doenças crônicas. A relação entre polifarmácia e sexo feminino, bem como sua associação com maior idade, estão em consonância com os resultados obtidos em outros estudos. Apesar da ausência de associação entre a polifarmácia e a escolaridade, os resultados de renda e plano privado de saúde reforçam a existência de desigualdades sociais em relação ao uso de medicamentos.

Palavras-chave: Farmacoepidemiologia. Polifarmácia. Saúde da população. Uso racional de medicamentos.

\section{INTRODUCTION}

The increasing worldwide use of multiple drugs is related to several factors, such as extended life expectancy and the consequent increase in multimorbidity prevalence. In addition, excessive drug use, usually referred to as polypharmacy, is also affected by the greater availability of medical treatments and therapeutic guidelines that recommend the use of more than one medication in dealing with several health conditions, such as hypertension and diabetes mellitus $^{1}$. If appropriately prescribed, drug association for treatment of different diseases may be required and beneficial to the patient ${ }^{2}$. However, some drug combinations are inappropriate and may lead to clinically relevant adverse reactions and drug interactions ${ }^{3}$.

Polypharmacy has been defined in different ways, and one of the most common definitions is the concomitant use of five or more drugs ${ }^{49}$. The use of multiple medications makes administering them difficult, reduces adherence to pharmacotherapy, and contributes to therapeutic duplication. In addition, polypharmacy has also been associated with increased risk of falls ${ }^{10}$, fractures ${ }^{11}$, hospitalizations ${ }^{12}$, and mortality ${ }^{13}$, as well as with a significant increase in social and household health expenditure ${ }^{14,15}$.

Studies that investigated polypharmacy are still limited, most of which focus on specific populations, such as the elderly ${ }^{6,7,9,16-18}$. Well-known factors associated with polypharmacy include an increase in age and a higher number of diseases ${ }^{9,18-24}$. Polypharmacy prevalence may reach $60 \%$ among people aged 65 years and older ${ }^{25,26}$, although high prevalence rates 
have also been observed among younger adults ${ }^{27-29}$. Comparatively, fewer studies investigated if socioeconomic characteristics, regardless of the presence of diseases, are associated with polypharmacy ${ }^{20,22,24}$, and the few existing results show diverging and inconclusive results. For example, a positive association between polypharmacy and education levels among adults and the elderly was detected in $\mathrm{Greece}^{24}$. However, a negative association was detected among the elderly in Belgium ${ }^{30}$ and Sweden ${ }^{20}$, while other studies detected no association between education levels and polypharmacy ${ }^{22}$.

From a clinical and public health standpoint, it is important to investigate the prevalence of polypharmacy among the middle-aged population, as it is a marker for multimorbidity, medication use quality, and potential adverse reactions. In addition, no information about the prevalence and the determinants of polypharmacy in Brazil, within this specific group, is available. Additionally, it generates opportunities to evaluate and intervene in pharmacotherapy that avoids exposing these individuals to polypharmacy for long periods of time, especially in vulnerable socioeconomic population, considering the existence of potential inequities in medication use demonstrated in some studies. In addition, no information about the prevalence and the determinants of polypharmacy in Brazil, within this specific group, is available. Therefore, this study is designed to estimate the prevalence of polypharmacy and to investigate if demographic and socioeconomic characteristics, regardless of the presence of diseases, are associated with polypharmacy among a large sample of Brazilians between 35 and 74 years of age.

\section{METHODS}

This is a cross-sectional study with participants in the Brazilian Longitudinal Study of Adult Health (ELSA-Brasil) baseline. ELSA-Brasil is a prospective cohort study that monitors active and retired public servants in public higher education and/or research institutions located in six state capitals in the Northeast, South, and Southeast regions of Brazil ${ }^{31}$. Data collection in ELSA-Brasil's baseline was conducted between 2008 and 2010, and it consists of 15,105 participants from 35 to 74 years of age. Detailed information about the ELSABrasil design and baseline participant characteristics have been provided in earlier publication $^{31}$. In the present study, ELSA-Brasil baseline included participants who exhibited valid data about demographic and socioeconomic characteristics, and who submitted complete information about their use of medications.

Like most national ${ }^{5-7,9,17,32,33}$ and international ${ }^{4,8,22}$ studies that have investigated the prevalence of polypharmacy, in the present work, polypharmacy was characterized by the use of five or more different drugs, used regularly, excluding phytotherapy preparations and homeopathic medications. Participants were instructed to bring all prescriptions, packages, inserts, and/or blisters for the medications they had used in the previous two weeks to the ELSA-Brasil Research Center. All medications, prescription or non-prescription, used regularly, produced industrially or by pharmacy compounding, in any form, were recorded 
here $^{31}$. The use of natural products, medicinal plants, or other preparations of the kind were not considered during the interview.

The following demographic and socioeconomic variables were also collected: gender (male/female); age (as a continuous variable); per capita household income (distributed by quintiles); education level (divided into years of study: under 8 , from 8 to 10, from 11 to 13 , and 14 or more); and health insurance (yes/no).

The variable number of chronic diseases was built taking into account the presence of any of the diseases listed as follow and was divided by the number of identified diseases: none (reference), one, two, or three or more. The diseases were defined by self-reported previous medical diagnosis for: diabetes; hypertension; dyslipidemia; cardiovascular disease, which corresponded to at least one of the clinical conditions: acute myocardial infarction, angina, congestive heart failure, cerebrovascular accident or stroke, and myocardial revascularization; as well as musculoskeletal disorders, that is, reports of rheumatoid arthritis and/ or osteoarthrosis and/or lupus erythematosus. We also included depression, constructed from face-to-face interviews, and then the sum of all types and severity of depressive episodes was determined by the Clinical Interview Schedule - Revised-CIS-R.

Initially, demographic and socioeconomic characteristics, diseases, and the total number of drugs were distributed among the entire population, and by the occurrence of polypharmacy. Categorical variables were described in proportion, and the continuous variable was described by average and standard deviation (SD). The comparison among proportions was conducted using the chi-squared test. Averages and their respective $95 \%$ confidence intervals $(95 \% \mathrm{CI})$ were estimated in raw form and adjusted by age, using linear regression, based on the number of diseases category. Absolute and relative drug frequencies, based on the first level of Anatomical Therapeutic Chemical (ATC) classification ${ }^{34}$, were distributed among the participants under polypharmacy treatment.

The association between polypharmacy and demographic and socioeconomic indicators was estimated by logistic regression and displayed as odds ratios (OR) with $95 \%$ confidence intervals $(95 \% \mathrm{CI})$. Initially, a univariate analysis was performed for each one of the demographic and socioeconomic characteristics, as well as for the number of diseases and polypharmacy variables (model 0 ). After this, gender and age were added (model 1), and, then, model 1 was adjusted by per capita household income, education level and health insurance (model 2). Finally, the number of diseases was included (model 3). All variables that remained statistically associated with the response variable $(\mathrm{p}<0.05)$ were maintained in the final model after all adjustments. This strategy made it possible to understand the effect of each variable on the model, which is important for understanding the phenomenon studied. All analyses were performed with the software Stata 12.0 and GraphPad Prism 7.

ELSA-Brasil was approved by the Research Ethics Committees at the learning and research institutions, as well as the National Research Ethics Committee, under the register number $976 / 2006$, and all interviewees signed the free and informed consent form.

This study was part of a master's thesis by the first author, entitled Polifarmácia e indicadores socioeconômicos: análise transversal do estudo longitudinal de saúde do adulto (ELSA-BRASIL), 
defended in April 2017 in the Post-graduate Program in Health Sciences at the Federal University of São João del-Rei.

\section{RESULTS}

Of the 15,105 ELSA-Brasil baseline participants, 118 (0.78\%) were excluded from the analysis because they did not adequately respond to the medication use questionnaire. Another 464 (3.07\%) questionnaires were not included in this study because they presented missing information on socioeconomic and demographic variables. Therefore, 14,523 $(94.15 \%)$ participants were included in the regression models. The majority were females $(54.4 \%)$ and had at least a college education $(52.1 \%)$. The average age of the population was 52.0 years $(\mathrm{SD}=9.1)$.

Polypharmacy prevalence was $11.7 \%$. Participants under polypharmacy treatment were significantly older, the majority of whom were women with lower education levels and higher per capita household income and, additionally, most of them had health insurance $(\mathrm{p}<0.001)$, if compared to the participants who used fewer than five drugs. In addition, the number referent to the frequency of disease was significantly higher $(p<0.001)$ among participants undergoing polypharmacy treatment (Table 1).

The recorded number of drugs used by participants was 727 . The number of medications varied between 0 and 35. The average of drugs used by the participants increased linearly according to the number of diseases, even after the age had been adjusted (Figure 1).

The most frequent drug classes used among the patients undergoing polypharmacy treatment were, in this order, those that act on the cardiovascular system, the digestive tract and metabolism, the nervous system, and the genitourinary system (Supplementary Table 1).

In this univariate analysis, women exhibited more likelihood to be under polypharmacy treatment if compared to men $(\mathrm{p}<0.001)$. A positive dose-response gradient was detected in the association between age and polypharmacy $(\mathrm{p}<0.001)$. Individuals with a lower education level (8 years of schooling or less) exhibited a greater chance of polypharmacy when compared to the group with a higher education level (14 years of schooling or more) $(\mathrm{p}<0.001)$. In terms of income, a negative gradient was detected in the association magnitude: the lower the income, the lower the chance of polypharmacy $(\mathrm{p}<0.001)$. Individuals without health insurance had lower chance to be under polypharmacy when compared to those who have it. The occurrence of polypharmacy also increased based directly on the number of diseases, suggesting a dose-response gradient in the association $(p<0.001)$ (Table 2$)$.

After being adjusted based on demographic and socioeconomic characteristics, all associations present in the univariate analysis were maintained. There was no substantial change in the associations' magnitudes, nor in their statistical significances. By adding the number of diseases variable to the previous model, the association between education level and polypharmacy lost its statistical significance, and the magnitudes of the associations between polypharmacy and age and the number of diseases suffered important reduction (Table 2). 
Table 1. Descriptive characteristics of the study population according polypharmacy occurrence, Longitudinal Study of Adult Health (ELSA-Brasil) (2008-2010).

\begin{tabular}{|c|c|c|c|}
\hline & $\begin{array}{c}\text { Total } \\
(n=14,523)\end{array}$ & $\begin{array}{l}\text { No polypharmacy* } \\
(\mathrm{n}=12,821)\end{array}$ & $\begin{array}{l}\text { Polypharmacy }{ }^{* *} \\
\qquad(\mathrm{n}=1,702)\end{array}$ \\
\hline \multicolumn{4}{|l|}{ Gender (\%) } \\
\hline Male & 45.6 & 46.9 & 35.1 \\
\hline Female & 54.4 & 53.1 & 64.9 \\
\hline \multicolumn{4}{|c|}{ Age (years) (\%) } \\
\hline $35-44$ & 22.2 & 24.3 & 6.5 \\
\hline $45-54$ & 39.5 & 41.3 & 26.2 \\
\hline $55-64$ & 27.9 & 26.5 & 38.7 \\
\hline $65+$ & 10.4 & 7.9 & 28.6 \\
\hline \multicolumn{4}{|c|}{ Education level (years) (\%) } \\
\hline $14+$ & 52.1 & 52.0 & 52.8 \\
\hline $11-13$ & 35.1 & 35.5 & 31.8 \\
\hline $8-10$ & 6.9 & 6.8 & 7.5 \\
\hline$<8$ & 5.9 & 5.7 & 7.9 \\
\hline
\end{tabular}

Per capita household income (quintiles) (\%)

\begin{tabular}{|l|l|l|l}
\hline 5 (highest) & 16.1 & 14.9 & 25.5 \\
\hline 4 & 22.5 & 22.2 & 24.4 \\
\hline 3 & 20.7 & 21.0 & 18.3 \\
\hline 2 & 20.3 & 20.9 & 15.7 \\
\hline 1 (lowest) & 20.4 & 21.0 & 16.1 \\
\hline
\end{tabular}

Health insurance (\%)

\begin{tabular}{|c|c|c|c|}
\hline \multicolumn{1}{|c|}{ Yes } & 67.9 & 66.8 & 76.2 \\
\hline No & 32.1 & 33.2 & 23.8 \\
\hline Number of diseases*** (\%) & \multicolumn{2}{|c}{} \\
\hline None & 22.6 & 25.0 & 4.9 \\
\hline 1 & 37.7 & 40.7 & 16.5 \\
\hline 2 & 24.3 & 23.6 & 29.4 \\
\hline $3+$ & 15.4 & 10.7 & 49.2 \\
\hline Number of drugs (mean \pm SD) & $1.8 \pm 2.3$ & $1.1 \pm 1.3$ & $6.7 \pm 2.3$ \\
\hline
\end{tabular}

*Non-polypharmacy: use of 0 to 4 medications; **Polypharmacy: use of 5 or more medications; ***diabetes mellitus and/or hypertension and/or cardiovascular disease and/or dyslipidemia and/or depression and/or musculoskeletal disease. Differences between participants with and without polypharmacy were statistically significant for all variables presented in the table $(p<0.001)$. The presentation of the average number of drugs used is descriptive and not compared between groups in polypharmacy and non-polypharmacy. 


\section{DISCUSSION}

This study, conducted with a large sample of Brazilian adults and elderly people, showed that approximately one in ten participants in the baseline was under polypharmacy treatment. After adjustments, including by number of diseases, the chances of being under polypharmacy treatment was significantly higher among women and older participants. Lower income participants without health insurance, however, had fewer chances of being under polypharmacy.

Some studies involving the general population conducted in other countries that used the same polypharmacy classification ${ }^{4,35}$ reported the prevalence of polypharmacy between 15.0 and $24.4 \%$, that is, much higher than that observed for the ELSA-Brasil baseline. One of the possible explanations for this difference is that drug use investigation in these studies referred to a 30 -day $^{4}$ and $12-$ month $^{35}$ period, which is greater than the period considered in the ELSA-Brasil study, which was 2 weeks. As is well-known, prevalence is a function of time, that is, the longer the time period considered, the higher an event's prevalence will be.

When compared to studies using the same reference period on drug use, the prevalence of polypharmacy found in the present study is also markedly lower than that observed in

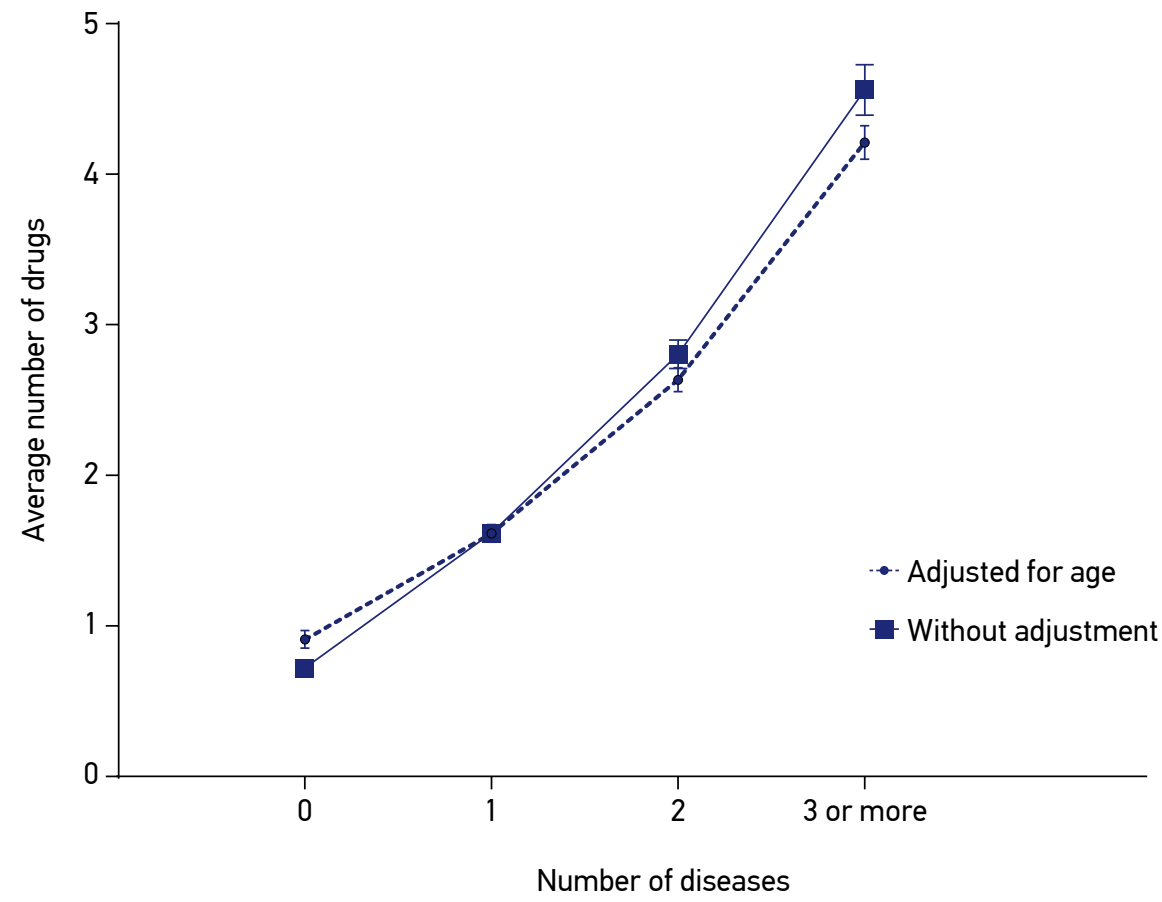

*Comorbidities: diabetes mellitus and/or systemic arterial hypertension and/or cardiovascular disease and/or dyslipidemia and/or depression and/or musculoskeletal disease.

Figure 1. Average of drugs used by participants according to the number of disease comorbidities*. 
cross-sectional studies conducted in municipalities in the Southeastern ${ }^{18,36,37}$, Midwest ${ }^{7}$, South ${ }^{38,39}$ and Northeast ${ }^{16}$ of Brazil. This difference was expected, given that the population interviewed in these studies was concentrated in elderly individuals. Moreover, these are

Table 2. Univariate and multivariate analysis of the number of diseases and demographic and socioeconomic characteristics and diseases associated with polypharmacy in Longitudinal Study of Adult Health (ELSA-Brasil) ( $n=14,523)$.

\begin{tabular}{c|c|c|c|c} 
& $\begin{array}{c}\text { Model 0 } \\
\text { OR }(95 \% \mathrm{Cl})\end{array}$ & $\begin{array}{c}\text { Model 1 } \\
\text { OR }(95 \% \mathrm{Cl})\end{array}$ & $\begin{array}{c}\text { Model 2 } \\
\text { OR }(95 \% \mathrm{Cl})\end{array}$ & $\begin{array}{c}\text { Model 3 } \\
\text { OR }(95 \% \mathrm{Cl})\end{array}$ \\
\hline \multicolumn{1}{|c|}{ Gender } & Reference & Reference & Reference & Reference \\
\hline Male & $1.63(1.47-1.82)^{*}$ & $1.78(1.59-1.98)^{*}$ & $1.72(1.54-1.93)^{*}$ & $1.79(1.58-2.02)^{*}$ \\
\hline Female & $1.10(1.09-1.11)^{*}$ & $1.10(1.09-1.11)^{*}$ & $1.09(1.08-1.10)^{*}$ & $1.05(1.04-1.06)^{*}$ \\
\hline Age (years) & & &
\end{tabular}

Education level (years)

\begin{tabular}{c|c|c|c|c}
\hline $14+$ & Reference & & Reference & Reference \\
\hline $11-13$ & $0.88(0.79-0.99)^{\star}$ & - & $1.34(1.17-1.55)^{\star}$ & $1.08(0.93-1.26)$ \\
\hline $8-10$ & $1.08(0.88-1.31)^{*}$ & - & $1.24(0.98-1.57)$ & $0.95(0.74-1.23)$ \\
\hline$<8$ & $1.36(1.12-1.66)^{*}$ & - & $1.44(1.13-1.83)^{\star}$ & $1.09(0.84-1.43)$ \\
\hline
\end{tabular}

Per capita household income (quintiles)

\begin{tabular}{|c|c|c|c|c|}
\hline 5 (highest) & Reference & & Reference & Reference \\
\hline 4 & $0.64(0.55-0.74)^{*}$ & - & $0.89(0.77-1.05)$ & $0.84(0.70-0.99)^{\star *}$ \\
\hline 3 & $0.51(0.44-0.60)^{*}$ & - & $0.77(0.65-0.92)^{*}$ & $0.67(0.55-0.82)^{*}$ \\
\hline 2 & $0.44(0.37-0.52)^{*}$ & - & $0.64(0.53-0.78)^{\star}$ & $0.52(0.42-0.64)^{*}$ \\
\hline 1 (lowest) & $0.45(0.38-0.53)^{\star}$ & - & $0.65(0.53-0.80)^{\star}$ & $0.51(0.41-0.65)^{*}$ \\
\hline \multicolumn{5}{|c|}{ Health insurance } \\
\hline Yes & Reference & & Reference & Reference \\
\hline No & $0.63(0.56-0.71)^{*}$ & - & $0.72(0.63-0.82)^{*}$ & $0.75(0.64-0.77)^{\star}$ \\
\hline
\end{tabular}

Number of diseases ${ }^{* * *}$

\begin{tabular}{l|c|c|c|c}
\hline None & Reference & - & - & Reference \\
\hline 1 & $2.06(1.59-2.67)^{\star}$ & - & - & $1.63(1.25-2.12)^{\star}$ \\
\hline 2 & $6.33(4.95-8.11)^{\star}$ & - & - & $4.31(3.34-5.57)^{\star}$ \\
\hline $3+$ & $23.43(18.36-29.90)^{\star}$ & - & - & $14.91(11.51-19.28)^{\star}$ \\
\hline
\end{tabular}

Model 0: crude analysis; model 1: gender + age (continuous); model 2: model 1 + educational level + per capita household income + health insurance; model 3: model 2 + number of diseases; OR: odds ratio; $95 \% \mathrm{Cl}$ : interval of confidence of $95 \%$; ${ }^{*} \mathrm{P}<0.001 ;{ }^{* *} \mathrm{P}<0$; ${ }^{* * *}$ diabetes mellitus and/or hypertension and/or cardiovascular disease and/or dyslipidemia and/or depression and/or musculoskeletal disease. 
unicentric studies and, although some were conducted in large Brazilian capitals, such as São Paulo $^{9}$, Rio de Janeiro ${ }^{40}$ and Porto Alegre ${ }^{38}$, they had a markedly less sample diversity than ELSA-Brasil. This limits the comparability of their results with those found in this paper.

In Brazil, the first population studies, representative of the five regions in the country, which investigated polypharmacy among urban area residents, used data from the National Survey on Access, Use, and Promotion of Rational Use of Medicines (PNAUM). Ramos et al. ${ }^{18}$, investigating polypharmacy using PNAUM data, observed an $18 \%$ polypharmacy prevalence in individuals 60 to 65 years of age or older. If the ELSA-Brasil elderly group (65-74 years of age) is considered alone ( $\mathrm{n}=1,504$ ), a polypharmacy prevalence of $32.3 \%$ is detected, which is almost double the PNAUM prevalence, even taking into account that this study's sample does not include the oldest group ( 75 years of age of more). However, it is important to note that PNAUM data included only continuous-use medication for the treatment of specific chronic diseases, while the ELSA-Brasil study included all medications used regularly, prescription or non-prescription, regardless of the therapeutic indication, which may well explain the detected differences.

Polypharmacy in the PNAUM was investigated exclusively among adults (18 years of age or older) and the elderly who use the primary health care services at the Brazilian Unified Health System (SUS). Although the time interval considered to investigate the use of medication (30 days) is longer than that adopted for ELSA-Brasil, the prevalence of polypharmacy in the primary healthcare services in the PNAUM was $6.9 \%{ }^{41}$, lower than that detected in the present study. In addition, the fact that the PNAUM study involves younger adults (starting at the age of 18) tends to reduce the global polypharmacy prevalence, considering that age, both in the PNAUM and the ELSA-Brasil study, was a factor associated with the occurrence.

The most frequent drug classes used among the patients undergoing polypharmacy treatment were, in this order, those that act on the cardiovascular system; the digestive tract and metabolism; and the nervous system. These results are similar to those observed in the adult and elderly groups included in the PNAUM ${ }^{41}$ and are compatible with the prevalence of other chronic conditions that affect these systems, considering that $40 \%$ of the participants in ELSA-Brasil were affected by at least two noncommunicable diseases (NCDs), which include those affecting the cardiovascular system (hypertension and/or cardiovascular disease), metabolism (diabetes or dyslipidemia), and the nervous system (depression). Another explanation would be prescribing doctors' adherence, in general, to the guidelines for treating these diseases. It is worth pointing out that guidelines and clinical protocols for treating NCD, despite being necessary, disregard certain specific circumstances in patient care. The prescription model that defines an individual drug therapy for each disorder has not often taking into account the population's aging and consequent increase of multimorbidity, resulting in an excessive use of medications observed in recent years ${ }^{41}$.

Results in this study corroborate other national ${ }^{7,9,32,39,41}$ and international ${ }^{42,43}$ studies that detected a higher chance of polypharmacy among women. Part of this association may be explained by the fact that the women use healthcare services more often ${ }^{44}$, for preventive care or for reproductive health purposes ${ }^{36}$, which creates different opportunities for 
diagnosis and, consequently, for drug prescription. In addition, women tend to adhere to prescribed treatments more than men, justifying why the association remained after adjusting for number of chronic diseases ${ }^{38,44}$.

In agreement with other studies' results ${ }^{4,9,16,24,32,37,43,45}$, polypharmacy was strongly associated with an increase in age and with a dose-response gradient. This result was independent on the adjustment by number of chronic diseases, which increases with aging ${ }^{46}$. Wastesson et al. ${ }^{47}$ estimated, based on the analysis of a drug dispensation database, that, after 75 years of age, Swedish elderly people would have been under polypharmacy treatment for more than half of the remaining period of life. Fragmentation of the biomedical model for the health approach, it should be noted, contributes to the increase in drug prescription and polypharmacy, as each specialist is responsible for treating a given morbidity, disregarding the overall realm of health problems exhibited by the individual ${ }^{48}$.

It is important to emphasize that, although association magnitude has been significantly reduced, and residual confounding may be present (adjustment by categories), age was maintained in strong association with polypharmacy, even after the adjustment by number of diseases, demonstrating that part of the effect of age on the occurrence of polypharmacy would not be explained by the higher number of diseases. Similarly, the number of diseases and polypharmacy, even when magnitude is reduced, remain strongly associated with one another, after adjustment by age. In addition, the average number of drugs grows linearly in line with the number of diseases, regardless of age. This suggests that, in fact, there is an effect, regardless of these two variables in the event of polypharmacy. These results reinforce the importance of discussing the healthcare practice called deprescribing ${ }^{49}$, which proposes revising pharmacotherapy and discontinuing previously prescribed drugs ${ }^{50}$.

In the present study, in the univariate analysis and after adjusting for other demographic and socioeconomic characteristics, an inverse association of polypharmacy with education was observed, that is, lower education was associated with a higher chance of polypharmacy. However, after adjusting for number of diseases, this association did not remain statistically significant, indicating that this association was, in fact, explained by the number of diseases, since the prevalence of this variable is higher among less educated individuals: among those who have completed higher education, $66.0 \%$ have one or no disease, whereas in the group of participants with incomplete elementary school, the prevalence of two or more diseases is $58.5 \%$.

Although some international studies do not detect this association ${ }^{6,22,39}$, national studies have identified similar results to this study's, that is, a lower chance of undergoing polypharmacy for participants with lower incomes and without health insurance, even after adjustment by number of disease ${ }^{9,51}$. Financially favored (higher incomes with health insurance) individuals tend to have more access to healthcare services, including the use of drugs ${ }^{22}$. In Brazil, the acquisition of medications in the public system still has deficiencies regarding storage, distribution, and dispensation ${ }^{51}$. In addition, public programs for access to pharmacological treatment of chronic diseases were incipient during the data collection phase of the present study. As previously discussed regarding education level, studies show that a 
doctor's decision to prescribe medications, especially the most expensive ones, is strongly influenced by the patient's socioeconomic conditions, which means those individuals with higher financial power tend to receive prescriptions with a higher number of drugs, especially newer and more expensive ones ${ }^{52}$.

The National Pharmaceutical Policies of $1998^{53}$ guaranteed access to medicine through the national public health care system (NPHS), SUS. Under the Popular Pharmacy of Brazil (Farmácia Popular do Brasil), created in 2004, medicines for hypertension, diabetes, and asthma are distributed free of charge (since 2011), and the Brazilian government covers $90 \%$ of the price of other medicines. It is also noteworthy that the data collection of the present study was performed before 2011. It is believed, however, that these policies for expanding access to medicines had no relevant impact on the prevalence of polypharmacy in ELSABrasil, considering the majority of baseline participants were covered by a health insurance, being less dependent on the free dispensation of medicines. Further studies in the ELSABrasil follow-up population may infer about the influence of these governmental measures on the prevalence of polypharmacy and their association with sociodemographic indicators related to access to medicines in this population.

In the present work, the use of medications was verified based on self-reports. Therefore, measurement errors may have occurred, which is a constraint of this work. To minimize the occurrence of such errors, participants were requested to bring prescriptions and packages for the medications they were using at the time of the interview. To avoid memory effects, participants were questioned about the use of regular medications only during the two weeks prior to the data collection.

The reference category of our polypharmacy classification (use of zero to four drugs versus use of five or more drugs) includes non-drug users and those who use less drugs in the same comparison group. However, it is the most used classification in epidemiological studies $^{8,22,32}$ and was adopted in this work to promoting dialogue with other publications. A classification with more than two categories, that would be more discriminatory, was considered during analyzes. However, the number of participants in the category of greatest use of drugs was very small, compromising the sampling power and the adjustment of the model.

Finally, the authors highlight that, although the population of ELSA-Brasil is limited to civil servants of educational and research institutions in the country and does not include unemployed individuals or those in extremely low socioeconomic position, the social, racial and regional diversity demonstrated in this cohort allows the investigation of relevant issues related to health inequities in a large sample of the Brazilian population. Furthermore, the prevalence of chronic conditions and health-related behaviors observed among participants of the ELSA-Brasil baseline was similar to the results found in VIGITEL, the surveillance system for risk and protection factors for chronic diseases by telephone survey held annually in all Brazilian capitals ${ }^{31}$.

The occurrence of polypharmacy among ELSA-Brasil baseline participants was mainly due to drugs for the treatment of chronic diseases. Despite the absence of an association between polypharmacy and education level, the income and health insurance results reinforce 
the existence of social inequalities regarding drug use. These findings may subsidize future epidemiological investigations related to excessive or inappropriate drug use, thus opening the door to the development of public policies that promote rational drug use in compliance with specific needs of the Brazilian population.

\section{ACKNOWLEDGEMENTS}

The authors thank the staff and participants of the ELSA-Brasil study for their important contributions.

\section{REFERENCES}

1. Cadogan CA, Ryan C, Hughes CM. Appropriate Polypharmacy and Medicine Safety : When Many is not Too Many. Drug Saf 2016; 39: 109-16. http:/ / doi. org/10.1007/s40264-015-0378-5

2. Bushardt RL, Massey EB, Simpson TW, Ariail JC, Simpson KN. Polypharmacy: Misleading, but manageable. Clin Interv Aging 2008; 3(2): 383-9. http:/ / doi.org/10.2147/CIA.S2468

3. Medeiros-Souza P, Santos-Neto LL, Kusano LTE, Pereira MG. Diagnosis and control of polypharmacy in the elderly. Rev Saúde Pública 2007; 41(6): 1049-53. http: / / doi.org/10.1590/S0034-89102006005000050

4. Hovstadius B, Astrand B, Petersson G. Dispensed drugs and multiple medications in the Swedish population: an individual-based register study. BMC Clin Pharmacol 2009; 9: 11. http:// doi. org/10.1186/1472-6904-9-11

5. Lucchetti G, Granero AL, Pires SL, Gorzoni ML. Fatores associados à polifarmácia em idosos institucionalizados. Rev Bras Geriatr Gerontol 2010; 13(1): 51-8. http:// dx.doi.org/10.1590/S1809-98232010000100006

6. Neves SJF, Marques APDO, Leal MCC, Diniz ADS, Medeiros TS, Arruda IKG de. Epidemiologia do uso de medicamentos entre idosos em área urbana do Nordeste do Brasil. Rev Saúde Pública 2013; 47(4): 759-68. http://doi.org/10.1590/ S0034-8910.2013047003768

7. Santos T, Lima D, Nakatani A, Pereira LV, Leal G, Amaral R. Consumo de medicamentos por idosos, Goiânia, Brasil. Rev Saúde Pública 2013; 47(1): 94-103. http: / doi.org/10.1590/S0034-89102013000100013

8. Yang M, Lu J, Hao Q, Luo L, Dong B. Does residing in urban or rural areas affect the incidence of polypharmacy among older adults in western China? Arch Gerontol Geriatr 2015; 60(2): 328-33. http: / / doi. org/10.1016/j.archger.2014.11.004
9. Carvalho MFC, Romano-Lieber NS, BergstenMendes G, Secoli SR, Ribeiro E, Lebrão ML, et al. Polifarmácia entre idosos do Município de São Paulo - Estudo SABE. Rev Bras Epidemiol 2012; 15(4): 817-27. http://dx.doi.org/10.1590/ S1415-790X2012000400013

10. Huang ES, Karter AJ, Danielson KK, Warton EM, Ahmed AT. The association between the number of prescription medications and incident falls in a multi-ethnic population of adult type- 2 diabetes patients: The diabetes and aging study. J Gen Intern Med 2010; 25: 141-6. http:// doi.org/10.1007/ s11606-009-1179-2

11. Lai S-W, Liao K-F, Liao C-C, Muo C-H, Liu C-S, Sung F-C. Polypharmacy correlates with increased risk for hip fracture in the elderly: a population-based study. Medicine (Baltimore) 2010; 89(5): 295-9. http:/ / doi. org/10.1097/MD.0b013e3181f15efc

12. Beer C, Hyde Z, Almeida OP, Norman P, Hankey GJ, Yeap BB, et al. Quality use of medicines and health outcomes among a cohort of community dwelling older men: An observational study. $\mathrm{Br}$ J Clin Pharmacol 2011; 71(4): 592-9. http:// doi. org/10.1111/j.1365-2125.2010.03875.x

13. Wang R, Chen L, Fan L, Gao D, Liang Z, He J, et al. Incidence and effects of polypharmacy on clinical outcome among patients aged 80+: A five-year follow-up study. PLoS One 2015; 10(11): e0142123. http:// doi.org/10.1371/journal.pone.0142123

14. Garcia LP, Sant'Anna AC, Magalhães LCG de, Freitas LRS de, Aurea AP. Gastos das famílias brasileiras com medicamentos segundo a renda familiar : análise da Pesquisa de Orçamentos Familiares de 2002-2003 e de 2008-2009. Cad Saúde Pública 2013; 29(8): 1605-16. http:/ / dx.doi. org/10.1590/0102-311X00070912 
15. Vieira FS. Gasto do Ministério da Saúde com medicamentos: tendência dos programas de 2002 a 2007. Rev Saúde Pública 2009; 43(4): 674-81. https: / / doi.org/10.1590/S0034-89102009005000041

16. Silva GDOB, Gondim APS, Monteiro MP, Frota MA, Meneses ALL De. Uso de medicamentos contínuos e fatores associados em idosos de Quixadá, Ceará. Rev Bras Epidemiol 2012; 15(2): 386-95. http:// doi. org/10.1590/S1415-790X2012000200016

17. Flores LM, Mengue SS. Uso de medicamentos por idosos em região do sul do Brasil. Rev Saúde Pública 2005; 39(6): 924-9. http:/ / doi.org/10.1590/ S0034-89102005000600009

18. Ramos LR, Tavares NUL, Bertoldi AD, Farias MR, Oliveira MA, Luiza VL, et al. Polypharmacy and Polymorbidity in Older Adults in Brazil: a public health challenge. Rev Saúde Pública 2016; 50(Supl. 2): 1-13. http:/ / doi.org/10.1590/s1518-8787.2016050006145

19. Moen J, Antonov K, Larsson CA, Lindblad U, Nilson JLG, Rastam L, et al. Factors associated with multiple medication use in different age groups. Ann Pharmacother 2009; 43(12): 1978-85. http:/ / doi. org/10.1345/aph.1M354

20. Haider SI, Johnell K, Weitoft GR, Thorslund M, Fastbom J. The influence of educational level on polypharmacy and inappropriate drug use: A registerbased study of more than 600,000 older people. J Am Geriatr Soc 2009; 57(1): 62-9. http://doi. org/10.1111/j.1532-5415.2008.02040.x

21. Nishtala PS, Salahudeen MS. Temporal trends in polypharmacy and hyperpolypharmacy in older new zealanders over a 9-year period: 2005 2013. Gerontology 2015; 61: 195-202. http:// doi. org/10.1159/000368191

22. Haider SI, Johnell K, Thorslund M, Fastbom J. Analysis of the association between polypharmacy and socioeconomic position among elderly aged $\geq$ 77 years in Sweden. Clin Ther 2008; 30(2): 419-27. http:/ / doi.org/10.1016/j.clinthera.2008.02.010

23. Hovstadius B, Petersson G. Factors Leading to Excessive Polypharmacy. Clin Geriatr Med 2012; 28(2): 159-72. http: / / doi.org/10.1016/j.cger.2012.01.001

24. Pappa E, Kontodimopoulos N, Papadopoulos AA, Tountas Y, Niakas D. Prescribed-drug utilization and polypharmacy in a general population in Greece: Association with sociodemographic, health needs, health-services utilization, and lifestyle factors. Eur J Clin Pharmacol 2011; 67: 185-92. http:/ / doi. org/10.1007/s00228-010-0940-0

25. Walckiers D, Heyden J Van Der, Tafforeau J. Factors associated with excessive polypharmacy in older people. Arch Public Heal 2015; 73. http: / / doi.org/10.1186/ s13690-015-0095-7
26. Moriarty F, Hardy C, Bennett K, Smith SM, Fahey T. Trends and interaction of polypharmacy and potentially inappropriate prescribing in primary care over 15 years in Ireland : a repeated cross-sectional study. BMJ Open 2015; 5: e008656. http: / / doi.org/10.1136/ bmjopen-2015-008656

27. Guthrie B, Makubate B, Hernandez-Santiago V, Dreischulte $T$. The rising tide of polypharmacy and drug-drug interactions: population database analysis 1995-2010. BMC Med 2015; 13. http://doi. org/10.1186/s12916-015-0322-7

28. Blozik E, Rapold R, Overbeck J von, Reich O. Polypharmacy and potentially inappropriate medication in the adult, community-dwelling population in Switzerland. Drugs Aging 2013; 30: 561-8. http:// doi.org/10.1007/s40266-013-0073-0

29. Payne RA, Avery AJ, Duerden M, Saunders CL, Simpson CR, Abel GA. Prevalence of polypharmacy in a Scottish primary care population. Eur J Clin Pharmacol 2014; 70: 575-81. http:/ / doi.org/10.1007/s00228-013-1639-9

30. Wauters M, Elseviers M, Vaes B, Degryse J, Dalleur O, Stichele RV, et al. Polypharmacy in a Belgian cohort of community-dwelling oldest old $(80+)$. Acta Clin Belg 2016; 71(3): 158-66. http:/ / doi.org/10.1080/17 843286.2016.1148298

31. Schmidt MI, Duncan BB, Mill JG, Lotufo PA, Chor D, Barreto SM, et al. Cohort profile: Longitudinal study of adult health (ELSA-Brasil). Int J Epidemiol 2015; 44(1): 68-75. http:// doi.org/10.1093/ije/dyu027

32. Dal Pizzol TDS, Pons EDS, Hugo FN, Bozzetti MC, Sousa MDLR De, Hilgert JB. Use of medication by the elderly in urban and rural areas in southern Brazil: a population-based study. Cad Saúde Pública 2012; 28(1): 104-14. http://doi.org/10.1590/ S0102-311X2012000100011

33. Nascimento AB do, Chaves EC, Grossi SAA, Lottenberg SA. A relação entre polifarmácia, complicações crônicas e depressão em portadores de Diabetes Mellitus Tipo 2. Rev da Esc Enferm da USP 2010; 44(1): 40-6. http: / / dx.doi.org/10.1590/S0080-62342010000100006

34. World Health Organization. ATC/DDD Index 2016 [Internet]. [accessed on Jan. 4, 2016]. Available at: http://www.whocc.no/atc_ddd_index/

35. Kantor ED, Rehm CD, Haas JS, Chan AT, Giovannucci EL. Trends in Prescription Drug Use Among Adults in the United States From 1999-2012. JAMA 2015; 314(17): 1818-30. http: / / doi.org/10.1001/jama.2015.13766

36. Andrade MV, Noronha KVM de S, Menezes R de M, Souza MN, Reis CB, Martins DR, et al. Desigualdade socioeconômica no acesso aos serviços de saúde no Brasil: um estudo comparativo entre as regiões brasileiras em 1998 e 2008. Econ Apl 2013; 17(4): 62345. http:/ / doi.org/10.1590/S1413-80502013000400005 
37. Reason B, Terner M, Moses McKeag A, Tipper B, Webster G. The impact of polypharmacy on the health of Canadian seniors. Fam Pract 2012; 29(4): 427-32. http:/ / doi.org/10.1093/fampra/cmr124

38. Tôrres Faggiani F, Schroeter G, Luz Pacheco S, et al. Profile of drug utilization in the elderly living in Porto Alegre, Brazil. Pharm Pract (Granada) 2007; 5: 179-184. Available at: https: / /www.scopus.com/inward/record. uri?eid $=2$-s2 $.0-37349120726 \&$ partnerID $=40 \& \mathrm{md} 5=\mathrm{a}$ $374182 f 8 a 76 b 2 b f 04150 b 1789 d 21 b 76$.

39. Galato D, da Silva ES, Tiburcio LDS. Study of the use of medicine in elderly living in a city in the South of Santa Catarina (Brazil): a look at the polymedication. Ciên Saúde Coletiva 2010; 15(6): 2899-905. http: / / doi. org/10.1590/S1413-81232010000600027

40. Rozenfeld S, Fonseca MJM, Acurcio F a. Drug utilization and polypharmacy among the elderly: a survey in Rio de Janeiro City, Brazil. Pan Am J Public Heal 2008; 23: 34-43. doi:10.1590/ S1020-49892008000100005.

41. Nascimento RCRM do, Álvares J, Guerra Junior AA, Gomes IC, Silveira MR, Costa EA, et al. Polifarmácia : uma realidade na atenção primária do Sistema Único de Saúde. Rev Saúde Pública 2017; 51 (Supl. 2): 1-12. http:/ / dx.doi.org/10.11606/ s1518-8787.2017051007136

42. Cashion W, McClellan W, Howard G, Goyal A, Kleinbaum D, Goodman M, et al. Geographic region and racial variations in polypharmacy in the United States. Ann Epidemiol 2015; 25(6): 433-8. http: / / doi. org/10.1016/j.annepidem.2015.01.018

43. Slabaugh SL, Maio V, Templin M, Abouzaid S. Prevalence and risk of polypharmacy among the elderly in an outpatient setting: a retrospective cohort study in the Emilia-Romagna region, Italy. Drugs Aging 2010; 27: 1019-28. http:// doi. org/10.2165/11584990-000000000-00000

44. Moraes SA de, Lopes DA, Freitas ICM de. Sexspecific differences in prevalence and in the factors associated to the search for health services in a population based epidemiological study. Rev Bras Epidemiol 2014; 17(2): 323-40. http://dx.doi. org/10.1590/1809-4503201400020004ENG

45. Mayer S, Österle A. Socioeconomic determinants of prescribed and non-prescribed medicine consumption in Austria. Eur J Public Health 2015; 25(4): 597-603. http:/ / doi.org/10.1093/ eurpub/cku179
46. Malta DC, Moura L de, Prado RR do, Escalante JC, Schmidt MI, Duncan BB. Mortalidade por doenças crônicas não transmissíveis no Brasil e suas regiões, 2000 a 2011. Epidemiol Serv Saúde 2014; 23(4): 599608. http:/ / doi.org/10.5123/S1679-49742014000400002

47. Wastesson JW, Canudas-Romo V, Lindahl-Jacobsen R, Johnell K. Remaining Life Expectancy With and Without Polypharmacy: A Register-Based Study of Swedes Aged 65 Years and Older. J Am Med Dir Assoc 2016; 17(1): 31-5. http:/ / doi.org/10.1016/j.jamda.2015.07.015

48. Marengoni A, Onder G. Guidelines, polypharmacy, and drug-drug interactions in patients with multimorbidity. BMJ 2015; 350. http:/ / doi.org/10.1136/bmj.h1059

49. Bolmsjö BB, Palagyi A, Keay L, Potter J, Lindley RI. Factors influencing deprescribing for residents in Advanced Care Facilities: insights from General Practitioners in Australia and Sweden. BMC Fam Pract 2016; 17: 1-11. http:// doi.org/10.1186/s12875-016-0551-7

50. Reeve E, Gnjidic D, Long J, Hilmer S. A systematic review of the emerging definition of 'deprescribing' with network analysis: implications for future research and clinical practice. Br J Clin Pharmacol 2015; 80(6): 1254-68. http:/ / doi.org/10.1111/bcp. 12732

51. Loyola Filho AI De, Uchoa E, Firmo JOA, Lima-Costa MF. Influência da renda na associação entre disfunção cognitiva e polifarmácia: Projeto Bambuí. Rev Saúde Pública 2008; 42(1): 89-99. http:/ / dx.doi.org/10.1590/ S0034-89102008000100012

52. Al-Windi A, Elmfeldt D, Svärdsudd K. The relationship between age, gender, well-being and symptoms, and the use of pharmaceuticals, herbal medicines and self-care products in a Swedish municipality. Eur J Clin Pharmacol 2000; 56(4):311-7. https://doi.org/10.1007/s002280000152

53. Brasil. Ministério da Saúde. Portaria $n^{\circ} 3.916$, de 30 de outubro de 1998 [Internet]. 1998 [accessed on Oct. 27, 2015]. Available at: http:/ /bvsms.saude.gov.br/bvs/ saudelegis/gm/1998/prt3916_30_10_1998.html

Received on: 10/22/2019

Revised on: 02/12/2020

Accepted on: 02/14/2020

Author's contributions: Isabella Ribeiro Silva and Roberta Carvalho de Figueiredo were responsible for data analysis, interpretation of results and writing of the article. The other authors collaborated with the interpretation of the results and writing of the article. 
DOI: https://doi.org/10.1590/1980-549720200077erratum

\section{ERRATUM / ERRATA}

In the manuscript "Polypharmacy, socioeconomic indicators and number of diseases: results from ELSA-Brasil”, DOI: 10.1590/ 1980-549720200077, published in the Rev. bras. epidemiol. 2020; 23: e200077, on page 1:

Where it reads:

Luana Giatti Gonçalves

It should read:

Luana Giatti 